\title{
Readiness of farmer groups to adopt the floating rice cultivation in Bojonegoro Regency, East Java Province
}

\author{
Heru Irianto $^{1,3}$, Mujiyo ${ }^{2}$, Aulia Qonita $^{1 *}$, and Erlyna Wida Riptanti $^{1,3}$ \\ ${ }^{1}$ Department of Agribusiness, Faculty of Agriculture, Universitas Sebelas Maret, Indonesia \\ ${ }^{2}$ Department of Soil Science, Faculty of Agriculture, Universitas Sebelas Maret, Indonesia \\ ${ }^{3}$ Study Center and Mentoring of Cooperation and Micro, Small and Medium Enterprises (CMSMEs), \\ Universitas Sebelas Maret, Indonesia
}

\begin{abstract}
This study aimed at investigating the preparedness of the local farmers as the agents of change for floating rice cultivation in a floodprone area. This study was carried out in Balungdowo Hamlet, Karangdayu Village, Baureno Sub-district, Bojonegoro Regency. The site was selected due to its flooded condition so that it met the criteria for the research location of floating rice cultivation. Samples for this research were taken using purposive sampling technique. The samples were two farmer groups cultivating floating rice. The data selecting instruments included observation, documentation, and interview. This research applied a qualitative method with descriptive approach. The results have shown that Farmers are not ready to implement floating rice technology, although floating rice cultivation is almost the same as other rice cultivation. Because the operational costs of floating rice cultivation are high, so it takes a lot of effort to ensure that floating rice cultivation can be done by minimizing costs by utilizing local natural resources. Moreover, most members of farmer groups are not at a productive age, with low education level (elementary school-graduated) and monthly income of fewer than IDR $1,000,000.00$.
\end{abstract}

\section{Introduction}

Agriculture has an essential function in improving economic conditions, food security conditions, reducing poverty, and developing rural areas [1]. In Indonesia, rice production experiences diversity in production due to climate influences. Extreme climatic conditions cause crops that experience prolonged failure. For example, there is a prolonged drought in the dry season and floods during the rainy season [2]. One area that is vulnerable to yearly flood is Bojonegoro Regency [3,4]. Bojonegoro has an area of 230,706 ha, $40.15 \%$ of which is state-owned forest area which is mostly located in the southern region of Bojonegoro. The remaining $32.58 \%$ of the area consists of paddy fields which are mostly located along the Bengawan Solo River [5]. If a flood happens, food crops will be water-

\footnotetext{
* Corresponding author: radenrara@staff.uns.ac.id
} 
logged, washed away, damaged and dead and this condition causes crop failure [6,7]. Food crops that are submerged by floods will occur every year from December to April.

The results of the study [8] on vulnerability and flood hazard level expose two significant points, namely : (1) "Less vulnerable level" is the most dominant vulnerability class with an area coverage of $80,712.03$ ha or $37.44 \%$ of the total area of Bojonegororo Regency, while the remaining areas are categorized very vulnerable (49,963.67 ha), vulnerable (77,351.15 ha) and non-vulnerable (7,580.16 ha). (2) Hazardous class is the most dominant category of flood hazard level with an area coverage of 93,274.07 ha or $43,261 \%$ of the total area of Bojonegoro Regency, followed by non-hazardous $(84,416.56$ ha), less hazardous (23,372.48 ha) and very hazardous (14,543.90 ha).

The government did many developing ideas on implementing mitigation and adaptation activities carried out by farming communities. These activities are a response to the vulnerability of agriculture and the contribution of activities to deal with climate change [9]. Universities, especially Universitas Sebelas Maret, in collaboration with the Department of Agriculture of Bojonegoro Regency, developed the technology of floating rice in the context of adaptation to rice cultivation under waterlogged conditions. Many previous studies were laboratory studies (demonstration plots) for 2 years to investigate the best floating media and planting media used with the lowest operational costs [4]. In the implementation of the floating rice technology demonstration plot, there were no obstacles. However, this technology has not yet been implemented at the farmer's level. This research is the final year research to find out farmers' preparedness as the agents of change of floating rice cultivation in flood-prone areas. Before this technology is widely applied, its applicability for farmers needs to be prepared.

Agricultural innovation has become a significant concern, because the parties who make decisions in agriculture are usually farmers' households, not companies [10]. Farmers are faced with limitations, risks and expectations of the results of floating rice cultivation. The agents of change can influence the speed of the diffusion process and the adoption of floating rice cultivation.

\section{Research method}

The qualitative method with a descriptive approach was applied in this research, based on the farmers around the demonstration plots (demplots) in Karangdayu Village, Baureno Sub-district, Bojonegoro Regency [11]. The floating rice cultivation system is a new form of innovation in growing rice, which is informed to farmers in areas always affected by flooding in Bojonegoro Regency [7]. Demplots as places of learning, information dissemination and and the process of spreading ideas is vital in the adoption of floating rice cultivation technology. The followings are the stages of this research.

\subsection{Determination of demplot area}

The research location was intentionally chosen in Bojonegoro Regency because the district is prone to flooding every year. The research was carried out in Karangdayu Village, Baureno District, because the village is flooded every year, so that it is suitable as a research location.

Demplots are located in strategic places, namely the rice fields on the side of the village road, so that the demonstration plots are easily seen and reached by farmers who pass through them. Farmers can observe directly the processes of making floating media and planting media, planting and harvesting. 


\subsection{Determination of floating rice cultivation demplot management}

Researchers invited representatives of farmer groups in Karangdayu Village and two people agree to manage the demonstration plots, which have a length of $20 \mathrm{~m}$ and a width of $10 \mathrm{~m}$. They came from the Mardi Rejeki farmer group. This farmer group is active in the area. The executors of these demplots are expected to become agents of change for floating rice cultivation.

\subsection{Demonstration of floating rice cultivation}

Demonstration plot (demplot) is a common method in community development and the demplot can be used as a sample of innovation and center of community learning [12]. It is an extension activity with demonstration method carried out by farmers as managers of demonstration plots to introduce ways of working or applying innovations, especially in making floating and planting media, planting spacing and planting to harvest.

Floating media uses bamboo. The planting medium used a mixture of soil and husk charcoal with a ratio of 1: 1 , and the spacing used was $25 \mathrm{~cm} \times 25 \mathrm{~cm}$. The bamboo used is old and brown, so it has a lighter density than bamboo still green. To prevent the bamboo from breaking when assembling the floating media, use plastic ropes with $5 \mathrm{~mm}$ and 10 $\mathrm{mm}$ diameter. This demonstration plot made four floating media units with specifications per unit of $6 \mathrm{~m} \times 2 \mathrm{~m} \times 20 \mathrm{~cm}$. The height of the planting medium is $15 \mathrm{~cm}$. It is estimated that rice roots are strong because they can penetrate the lower limit of the floating media using only woven bamboo. Demplots of floating rice cultivation are presented in Figure 1 and Figure 2.

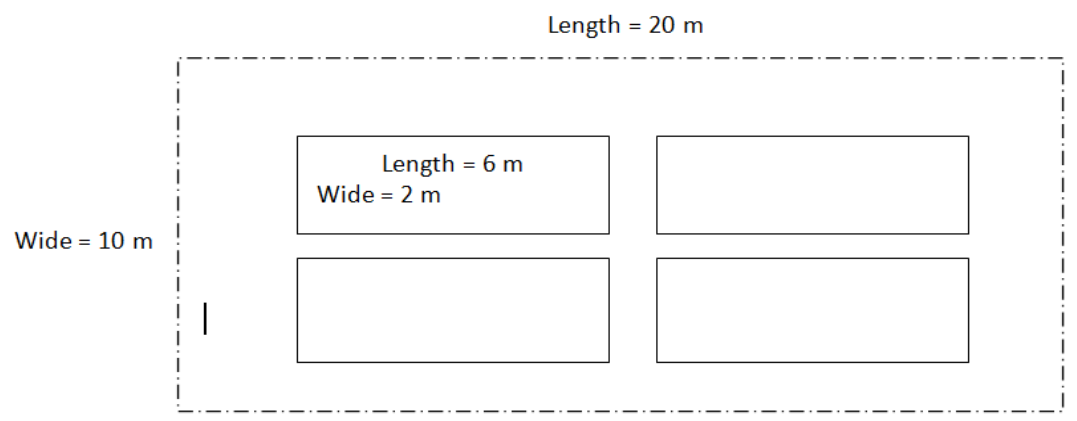

Fig. 1. Demonstration plot desain.

The planting medium used in the form of soil and husk charcoal is mixed to be homogeneous. Homogeneous planting media will make plant growth synchronously. The rice variety planted is IR-64 because it has a short harvest life.
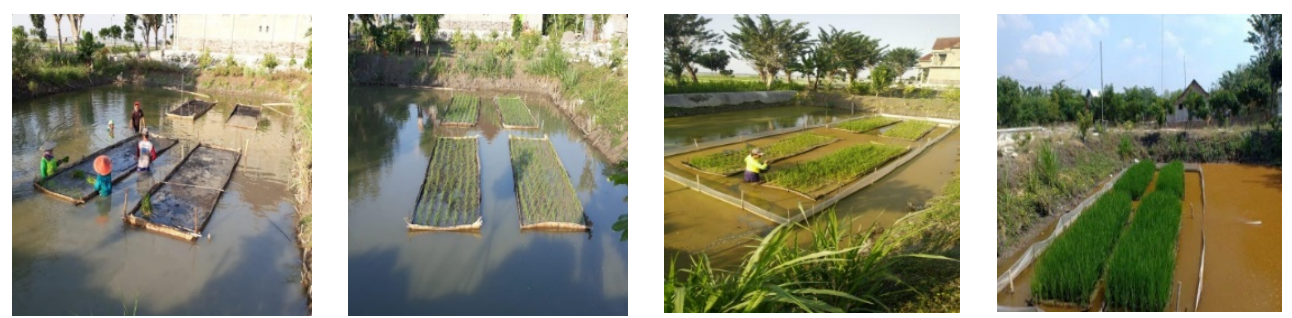

Fig. 2. Floating rice demonstration plot in Karangdayu Village, Baureno Sub-district, Bojonegoro Regency. 


\subsection{Monitoring and evaluation of technical skills and soft skills.of floating rice demplot managers}

The evaluation focused on the preparedness of the agents of change in managing the demonstration plot and introducing it to other farmers around the site. The research population is farmers around the floating rice cultivation demonstration plot. Farmers who live around the demonstration plot or farmers who have rice fields close to the demonstration plot location have a maximum radius of $3 \mathrm{~km}$. The research sample or research respondents were 200 farmers, which were taken purposively.

\section{Results and discussion}

Agricultural technology is considered an excellent solution to overcome the poverty that is prevalent in many developing countries [1]. Adopting better technology in agriculture can be seen as an excellent solution to the poverty experienced by some developing countries [13]. Innovations in agriculture often experience delays in the adoption process, and some aspects are not well understood [14]. Improved technologies are not adopted immediately [15]. When carrying out the adoption process, small-scale experiments in agriculture are the main thing to do. There are several essential and primary recommendations for implementing technology related to environmental conditions [16].

Demonstration plots are a method of agricultural extension in the field to show clearly the ways and/or the results of agricultural technology applications that have been proven beneficial for farmers. Demplots are live demonstrations which benefits can be seen, analyzed, evaluated and obtained by farmers. This demonstration method will be more effective if supported by other methods appropriate for the effort to disseminate knowledge and skills. Demonstrators are the people chosen and guided by agricultural extension workers and researchers. They carry out demonstrations to convince other farmers.

Demonstration activities are aimed at improving farmers' knowledge, skills and ability to absorb information, the planning process, cooperation and effectiveness. The ability to conduct demonstration plot activities is expected to have a positive impact on changes in farmers' attitudes towards the absorption and application of floating rice cultivation technology.

The followings are the results of research on evaluation of demonstration plot implementation for farmers in Mardi Rejeki farmer group as the agents of change.

\subsection{The internal condition of demonstrators}

In general, the level of education of farmers influences the ability of farmers regarding literacy, insight, and understanding of farmers [17]. The high level of education can supports loyality to the state (nationalism) and the knowledge possessed by farmers about the development and adoption of new technology that can be used in managing their farming business. Education of the farmer has been assumed to have a good and positive influence on the way farmers make decisions to adopt new technology. Farmer who have a high level education can improve their ability to obtain information, process information and use information relevant to the new technology adoption activity [18,19]. The average level of education of demonstrators and farmer groups is relatively low (elementary schoolgraduated) where it is the same as the average education of farmers in the region [7]. The relatively low level of education affects the ability of demonstrators to properly communicate demplots to other farmers in the vicinity. 
The age of the farmer can also determine the decision to adopt new technology. Older farmers are assumed to have gained a lot of knowledge and experience in farming over time and evaluate information on technology better than younger farmers do [19,20]. The average members of the farmer group implementing the demonstration plot are considered old (non-productive age), which is more than 64 years old (Table 1). This is because the regeneration level in the field of farming is low. Youngsters from this area are mostly looking for jobs outside the area, as factory workers, commerce and services.

Table 1. Respondent Characteristics.

\begin{tabular}{|c|l|c|c|}
\hline No & \multicolumn{1}{|c|}{ Characteristics } & Number (Person) & Percentage (\%) \\
\hline 1. & Age Group & 77 & 38,5 \\
\hline & Productive age (15-64 years) & 123 & 61,5 \\
\hline & Non-productive age (>64 years) & 200 & 100 \\
\hline & Total & 111 & 55,5 \\
\hline 2 & Length of Education & 52 & 26,0 \\
\hline & 6 years (Graduated elementary school) & 33 & 16,5 \\
\hline & 9 years (Graduated junior high school) & 4 & 2,0 \\
\hline & 12 years (graduated senior high school) & 200 & 100 \\
\hline & $>12$ years (Graduated from college) & & \\
\hline & Total & & \\
\hline
\end{tabular}

Data Source: Primary data analysis (2018)

\subsection{Readiness of farmer group in the aspects of knowledge, skills and mastery of adoption material in floating rice cultivation}

In developing countries, several factors influence the adoption of production technology, namely various economic, social, physical, and technical aspects of agriculture. The role of these factors is essential to understand to ensure that technology is developed correctly and development projects are successful [21]. Some constraint to adoption extreme weather, liquidity constraints, awareness of technologies [22]. These are good exposure for the low adoption rate of improved agricultural technologies.

Demonstrators are familiar with variations of weather and climate in this area, and therefore, they can easily adapt to the condition in floating rice cultivation. Their awareness of the existence of floating rice cultivation has been noticed since 2017. This farmer group follows the development of floating rice technology modification.

The adoption process has several parts, one of which is the ability of farmers to apply their knowledge to modify and adapt existing technology. When trying to understand the decision to adopt an innovation, a researcher should ensure that farmers have taken the time to assess the stages of the adoption process. The adoption process starts from initial adoption to technology adaptation or modification [23].

The farmer group, particularly farmer demonstrators, is already prepared, having the knowledge, skills and mastery of floating rice cultivation. Floating rice cultivation is technically the same as that of rice cultivation in general. The difference lies in the media for planting and harvesting. Farmers grow and harvest rice on floating media [2] so that the farmers can adopt floating rice cultivation demplots. As many as $27 \%$ of farmers think that floating rice cultivation is easy to implement, and $73 \%$ of farmers think that floating rice cultivation is difficult to implement. 


\subsection{Farmer group preparedness in term of economic adoption in floating rice cultivation}

Diffusion carried out by individuals results from an individual's decision to use new technology. The decisions taken are often the result of comparing the uncertainty of the benefits of a new invention with the uncertainty of the costs involved in adopting it [24]. Floating rice cultivation requires a fixed cost of IDR. 1,005,950, consisting of equipment depreciation costs of IDR. 973,950, land tax costs of IDR. 2,000, and capital interest costs of IDR. 30,000. Floating rice cultivation requires a variable cost of IDR. 246,055, which consists of the cost of husk charcoal of IDR. 50,000; The cost of organic pesticides is IDR. 5,000; Labor costs of IDR. 160,000; The cost of urea fertilizer is IDR. 907; Phonska fertilizer costs IDR. 27,648; The cost of rice seeds is IDR. 2,500. Revenue from floating rice cultivation is IDR. 170,500, with Dry Rice Grain as much as $31 \mathrm{~kg}$, and the price per kilo is IDR. 5,500. The profit obtained is non-existent because it suffered a loss of IDR. $1,081,505$ and an efficiency of 0.14. [4]. Demplot implementing farmers receive financial supports from researchers so that the operational costs of floating rice cultivation are still borne by researchers. The operational costs of floating rice cultivation are not low, compared to the economic condition of the farmer households in the area. The highest household income is less than IDR 1,000,000 / month [7].

If farmers and farmer groups independently adopt demplots, they require high operational costs so that financial capital becomes a constraint [23,25]. Studies on adoption by economists have received less attention regarding the role of farmer preferences in decision-making [26]. Economically, this technology has not provided benefits [4] but has provided grain production in the context of achieving food security in flooded areas. Grain production will increase food availability and reserves in the rainy season.

This technology still needs modification so that operational costs can be affordable for farmers in the area that is prone to flood. Farmers utilize their resources including bamboo, husk ash and family labor. Much of the knowledge to be gained about the adoption of new technologies comes from time-series evidence [27]. Therefore it is necessary to prove in time series that farmers can use their resources for floating rice cultivation so that the operational costs can be lower and the income can be more promising.

\subsection{Farmer group preparedness in the aspect of adoption risk in floating rice cultivation}

An individual's decision about the optimal combination of actions or practices depends on his/her perception of expected profit, risk and attitude to risk [28]. To this point, rice fields in flooded areas are not used for agricultural activities because farmers/ farmer groups are risk aversion [29]. Failure to plant and loss of production at the time of harvest will make farmers/ farmer groups reluctant to cultivate rice or other crops during the rainy season.

These understanding and behavior are still carried out by most of the demonstrators in the Mardi Rejeki farmer group in the technology adoption process. Farmers' behavior towards risk [21] is obvious in their responses, in which they do not easily take any risk in the adoption of floating rice cultivation. In general, these farmers take crop failure into account due to pests and diseases. This is so because if the cultivation of floating rice is not carried out by all farmers at the same time flooded area, pest and disease will potentially great attack. To minimize pest and disease attacks, farmers carry out intensive maintenance of floating rice. 


\subsection{The roles of agricultural extension agents in the diffusion process}

A farmer can learn and take knowledge from technology experiments. Technical advice and information needed can be available from extension officers or information media. If farmers have the same conditions, then the process of learning about new technologies can be social. Farmers can learn about the conditions characteristic of new technologies derived from experiments conducted by neighbors [30].

Agents' behavior and characteristics affect the behavior of other network members, giving rise diffusion. Based on the theory of diffusion and innovation, it is known that contact and contact with extension workers can positively influence adoption. These contacts can be known to farmers about the availability of information that you can do to make adoptions [31]. Availability of qualified agricultural extension workers, motivation, commitment, and always responsive to changes in social, economic, and political conditions, can affect the effectiveness of agricultural extension work [32]. The frequency of agricultural extension visits influences the learning process of farmers [33]. The agents accompany the demonstrators of demonstration plot/ farmer group in the learning process of the floating rice demonstration plot. This improves the learning process and the comprehension of demonstrators/ farmer. The roles of the field extension agents are very important in disseminating information and providing extension on demonstration plots $[23,25]$.

Based on respondents' assessment of the role of agricultural extension agents as an educator, it is known that $91 \%$ of farmers consider that an agricultural extension agent is an educator who can assist in the learning process in the floating rice cultivation demonstration plot. As many as $89 \%$ of farmers considered agricultural extension agents reforming agents, who disseminated information about floating rice cultivation. As many as $84 \%$ of farmers consider that agricultural extension agents are dynamists who can encourage and motivate farmers to be more active, enthusiastic, and creative, increasing their willingness to learn about floating rice cultivation demonstration plots.

The ability of farmers/ farmer group as the agents of change of floating rice cultivation with various limitations needs to be improved. Capacity building with extensive training is essential for farmers to adopt new technologies [34] and consulting services with agricultural extension workers, as well as agricultural associations are essential to adopt new technology in agriculture [18]. Modification of low-cost floating media by utilizing the resources of farmers can improve the adoption process.

Several research results show that policy interventions that can motivate the implementation of technology adoption are influenced by the type of new technology, the existing market structure, the nature of the policy intervention, and the duration of the policy intervention [10]. In this case, the adoption of technology requires government policies related to the spread of floating rice cultivation technology in sub-districts which are prone to flood. Demonstration expansion at the farmer group level needs to be done in accelerating adoption.

\section{Conclusion}

Farmers are not ready to implement floating rice technology. Because the technology of floating rice cultivation is new for farmers/ farmer groups in flooded areas in Bojonegoro Regency. Farmers around the demonstration plot areas are still waiting and observing the development of the demonstration plots. The limited ability of demonstrators contributes to inadequate delivery of information of technology from the agents to the other farmers. The agents of change need assistance from the researchers and agricultural extension officers in the working area. The extension officers are also supported by the government. 
Acknowledment. The authors would like to thank Universitas Sebelas Maret for funding and granting permission for this research with the Hibah Unggulan UNS scheme in 2019. The authors also deliver their gratitude to the Head of the Agricultural Technical Implementation Unit of Baureno Sub-district, the field extension officers and all parties who assisted the researchers in the preparation of this article.

\section{References}

1. M. Mwangi, S. Kariuki, J. Econ. Sustain. Dev. 6, 208-216 (2015)

2. H. Irianto, Mujiyo, E. W. Riptanti, A. Qonita, IOP Conf. Ser. Earth Environ. Sci. 142 (2018)

3. E. W. Riptanti, S. Supardi, R. Aulia Qonita, Int. J. Appl. Environ. Sci. 11, 1435-1450 (2016)

4. E. W. Riptanti, Mujiyo, H. Irianto, A. Qonita, Ecol. Environ. Conserv. 25, 61-66 (2019)

5. K. T. Prasetijo, Laporan Semester I 2016 Pejabat Pengelola Informasi Dan Dokumentasi Pemerintah Kabupaten Bojonegoro (2016)

6. S. Supardi, E. W. Riptanti, A. Qonita, J. AGRISEP. 13, 76-91 (2014)

7. H. Irianto, Mujiyo, A. Qonita, E. W. Riptanti, IOP Conf. Ser. Earth Environ. Sci. 314, (2019)

8. M. L. Aziz, Pemetaan Tingkat Kerentanan Dan Tingkat Bahaya Banjir Daerah Aliran Sungai (DAS) Bengawan Solo Bagian Tengah Di Kabupaten Bojonegoro, Skripsi Universitas Negeri Yogyakarta (2012)

9. V. R. Haden, M. T. Niles, M. Lubell, J. Perlman, L. E. Jackson, PLoS ONE. 7, (2012)

10. G. Feder, D. L. Umali, Technol. Forecast. Soc. Change. 43, 215-239 (1993)

11. Sugiyono, Metode Penelitian Bisnis (Penerbit Alfabeta, Bandung, 2014)

12. B. Uripno, L. M. Kolopaking, R. M. Slamet, S. Amanah, Int. J. Sci. Eng. 7, 81-90 (2014)

13. F. Simtowe, M. Kassie, A. Diagne, S. Asfaw, B. Shiferaw, S. Silim, E. Muange, Q. J. Int. Agric. 50, 325-345 (2011)

14. O. Bandiera, I. Rasul, Econ. J. 116, 869-902 (2006)

15. A. Maertens, C. B. Barrett, Am. J. Agric. Econ. 95, 353-359 (2013)

16. M. Marra, D. J. Pannell, A. Abadi Ghadim, Agric. Syst. 75, 215-234 (2003)

17. L. Zamzami, A. Sugiyatno, H. Harwanto, Caraka Tani J. Sustain. Agric. 36, 144-154 (2021)

18. R. N. Uaiene, C. Arndt, W. A. Masters, Determinants of Agricultural Technology Adoption in Mozambique, Discussion Papers No. 67E National Directorate of Studies and Policy Analysis Ministry of Planning and Development Republic of Mozambique (2009)

19. D. B. Mignouna, V. M. Manyong, J. Rusike, K. D. S. Mutabazi, E. M. Senkondo, AgBioForum 14, 158 (2011)

20. K. Kariyasa, Y. A. Dewi, Int. J. Food And Agricultural Econ. 1, 29-38 (2013)

21. Y. Kebede, K. Gunjal, G. Coffin, Agric. Econ. 4, 27-43 (1990)

22. A. Diagne, M. Demont, Agric. Econ. 37, 201-210 (2007)

23. A. A. Adesina, J. Chianu, Agrofor. Syst. 55, 99-112 (2002)

24. Loevinsohn M, Sumberg J, Diagne A, Under What Circumstances and Conditions Does Adoption of Technology Result in Increased Agricultural Productivity? Protocol, EPPI Centre, Social Science Research Unit Institute of Education University of London, London (2012)

25. T. B. Below, K. D. Mutabazi, D. Kirschke, C. Franke, S. Sieber, R. Siebert, K. Tscherning, Glob. Environ. Chang. 22, 223-235 (2012) 
26. A. A. Adesina, J. Baidu-Forson, Agric. Econ. 13, 1-9 (1995)

27. T. Besley, A. Case, Am. Econ. Rev. 83, 396-402 (1993)

28. A. K. Abadi Ghadim, D. J. Pannell, Agric. Econ. 21, 145-154 (1999)

29. P. Koundouri, C. Nauges, V. Tzouvelekas, Am. J. Agric. Econ. 88, 657-670 (2006)

30. T. Conley, C. Udry, Am. J. Agric. Econ. 83, 668-673 (2001)

31. R. A. Polson, D. S. C. Spencer, Agric. Syst. 36, 65-78 (1991)

32. K. Belay, D. Abebaw, African Dev. Rev. 16, 139-168 (2004)

33. P. Krishnan, M. Patnam, Am. J. Agric. Econ. 96, 308-327 (2014)

34. S. A. Oni, L. L. Maliwichi, O. S. Obadire, African J. Agric. Res. 6, 2188-2197 (2011) 